Genetic testing for sports performance

\section{Comment: genetic test available for sports performance}

\section{J Savulescu, B Foddy}

\section{Genetic testing for sports performance introduces ethical problems for parents}

$\mathrm{F}$ or the first time, we can now obtain a cheap and non-invasive genetic test, which tells us not if we have a disease or whether we are related to our parents, but what kind of sports we are likely to be good at.

For AUD\$110, the Australian company Genetic Technologies will test a cheek swab for the R577X variant of the ACTN3 gene. This gene normally produces the protein $\alpha$-actinin-3, which helps to produce the fast twitch muscles used in sprint and power sports. The $\mathrm{R} 577 \mathrm{X}$ variant is a common version of this gene which produces less of this protein. People with this variant therefore will grow less fast twitch muscle tissue in their body.

The test does not identify whether a person is good or bad at sport or athletics. A person with no copies of the R577X variant gene should perform better than average in sprints and power sports such as judo. A person with two copies of this gene should be good at long distance or endurance sports. A person with one copy of each variant will be positioned between these two extremes.

People were horrified when Professor Deon Venter, head pathologist at Genetic Technologies, announced that he had performed this test on his children. But Venter has not harmed his children, nor has he subjected them recklessly to a dangerous unknown. We already look to identify a person's particular talents when they are very young. Children with nimble fingers and perfect pitch are encouraged to play the violin, and children who grow tall at a young age are encouraged to play basketball. The new test is only different in that it enables us to make one such judgment before a person is born.

The ACTN3 test does not guarantee a person's ability to be an elite athlete, and today we have much more sophisticated talent selection tests. But genetic tests will increasingly play a role in identifying the biological potential of the would-be elite athlete.

Of course genetic tests like this can be abused. There are parents who will put their child under tremendous pressure to be an elite sprinter because they show the appropriate genetic aptitude. When advances in technology let us predict if our fetus will be an overall athletic success, we will no doubt be tempted to place talented children in training during their infancy. These choices would make us bad coaches, and bad parents, for putting sporting performance ahead of a child's wellbeing. But the technology will not make bad parents out of good parents. Good parents understand that these kinds of pressures can make for a harrowed, unhappy childhood.

Perhaps the worst thing we could do with this and any other talent test is to exclude people who lack the talent for a particular sport from participating in it. We have become an obese, sedentary, lazy race. It is of key importance to worldwide health that participation in sport is maximised in every population group. Parents, in particular, should support their children's sporting involvement no matter what kind of aptitude they have. Indeed, parents could use this test to encourage a lazy or sceptical child to get involved in sport.

People often voice concerns about how genetic technologies may lead parents to treat their children. It is up to parents to be kind to their children, and to support their autonomy and personal growth. A parent who wants to oppress their child, to live through them or to make their life miserable in some way can already do this with great efficiency without using genetic technology. Therefore such a test poses no additional risks to a child.

The human species has an accountant's obsession with measurements and tests, but the one test that matters in sport is sporting performance. No matter how much of athletic biology we understand, we will never understand everything that separates winners and losers in sport. We hope that selectors for the Olympics and other elite sports will have the good sense and humility to base selections on performance rather than on genetic aptitude.

Br J Sports Med 2005;39:472.

doi: 10.1136/bjsm.2005.017954

\section{Authors' affiliations}

J Savulescu, Uehiro Chair of Practical Ethics, University of Oxford, Oxford, UK B Foddy, Murdoch Children's Research Institute, Melbourne, Victoria, Australia

Correspondence to: Bennett Foddy, Ethics Unit, Murdoch Research Institute, Royal Children's Hospital, Flemington Road, Parkville, Melbourne, Victoria 3052, Australia; bennet@ foddy.net

Competing interests: none declared 